\title{
THE OCCURENCE OF ECOLOGICAL TRAPS IN BIRD POPULATIONS: IS OUR KNOWLEDGE SUFFICIENT? A REVIEW
}

\author{
PETR Suvorov, JANA SvOBODOVÁ \\ Czech University of Life Sciences, Faculty of Environmental Science, Kamýcká 129, CZ- \\ 16521 Prague 6, e-mail: petr.suvorov@hotmail.com, svobodovajana@fzp.czu.cz
}

Received: $9^{\text {th }}$ August 2012, Accepted: $14^{\text {th }}$ December 2012

\begin{abstract}
Anthropogenic changes in a landscape create new cues for birds, which must permanently adapt to these. If landscape changes occur too quickly, individuals have insufficient time to develop adequate reactions. They may, therefore, preferentially nest in low-quality habitats, which can lead to diminished nesting success and to reduction of their population size. This is usually termed the ecological trap hypothesis. We reviewed 38 studies investigating this phenomenon and analysed whether relationships exist between ecological trap occurrence and geographical region, habitat type, and/or life strategies of bird species. Ecological traps were most often associated with the presence of exotic species. Exotic species can modify environmental conditions in ways to which native communities are not adapted. They have been mainly detected in open habitats. Such open habitats as arable fields and meadows are under greater human pressure, and rapid changes probably occur there more frequently. Although more studies from North America were investigated, the hypothesis was supported more frequently in European studies. This is possibly due to higher human population density and, hence, more frequent habitat changes. Our results show that an ecological trap is not likely associated with migration. Ground nests suffered fewer consequences of such traps than did other nest types. Although the implications of the ecological trap hypothesis in species conservation are undisputable, a more detailed approach is still needed. For instance, some habitat types, such as suburban areas, have been neglected in the context of ecological traps, as has been the phenomenon's appearance in pristine habitats.
\end{abstract}

Key words: edge effect, exotic species, habitat fragmentation, life strategies, nest predation, nesting success

\section{INTRODUCTION}

Correct selection of a nesting site is one of the most essential factors attributed to nesting success in birds (e.g. Bayne and Hobson 2001; Shochat et al. 2005). Birds choose their nesting sites based on environmental characteristics such as species composition or density of vegetation, because, in a natural environment, these indicate sufficient availability of food and shelters, which, in turn, have positive effects on the reproductive success of individuals (Schlaepfer et al. 2002; Aldridge and Boyce 2007; Powell et al. 2010). In a rapidly changing environment, however, these characteristics do not necessarily possess the same indicative value (Gates and Gysel 1978; Vergara and Simonetti 2003; Shochat et al. 
2005), because they may be associated with factors, such as high rate of nest predation, parasitization and disturbance (Marzluff and Ewing 2004; Mannan et al. 2008), that can outweigh the effects of positively acting factors. If individuals of higher fitness preferentially nest in biotopes where they nevertheless achieve lower nesting success, then this habitat is said to be an ecological trap (Dwernychuk and Boag 1972; Gates and Gysel 1978; Robertson and Hutto 2006; Pelicice and Agostinho 2008). This phenomenon can cause decrease in bird abundance (Kokko and Sutherland 2001; Ries and Fagan 2003; Gilroy and Sutherland 2007; Lindell 2008; Pärt et al. 2007; Kriska et al. 2008) and, in extreme cases, can lead to local extinction of entire populations (Reed 1999; Schlaepfer et al. 2002; Ries and Fagan 2003).

An ecological trap is usually linked to a human-altered habitat, and mostly due to habitat fragmentation or the presence of exotic species (Battin 2004). If a new species of animal or plant is introduced into a particular environment, it can either directly (through predation, competition, parasitization or genetic hybridisation) or indirectly (e.g. by affecting vegetation structure, which can lead to higher nest predation) negatively influence the reproductive success of native species (Mack et al. 2000; Schlaepfer et al. 2005; Campomizzi et al. 2009). In many places, birds must cope with excessive habitat fragmentation (Fernández - Juricic and Jokimäki 2001), which causes a loss of suitable nesting biotopes and increases the proportion of marginal biotopes relative to inner ones (Andrén and Angelstam 1988; Bosschieter and Goedhart 2005; Fahrig 2003; Manu et al. 2007). Some biotope interfaces, however, can be attractive to nesting birds for such reasons as vegetation heterogeneity (Hansson 1994; Fernandez - Juricic et al. 2001; Brotons and Herrando 2003; Batáry et al. 2004; Berg 2008) or easy access to complementary resources from neighbouring biotopes (Ries and Sisk 2004). Due to a higher concentration of resources, however, there is also an elevated density of especially omnivorous (nonspecialized) species of predators such as Red Fox (Vulpes vulpes), martens (Martes sp.) or corvids (Corvidae) (Andrén 1992; Paton 1994; Chace and Walsh 2004; Marzluff and Neatherlin 2006), which profit from the presence of humans and can lower the reproductive success of birds through increased predation of their nests (i.e. due to so-called edge effect on nest predation). When birds nest in edge habitats in higher densities than in interior biotopes, and simultaneously achieve lower reproductive success there because of higher nest predation, they may have been lured into an ecological trap (Weldon and Haddad 2005).

Birds choose their nesting sites based not only on their evolutionary history but also on their acquired experiences (Kokko and Sutherland 2001; Miner et al. 2005; Parejo et al. 2006, Keeler and Chew 2008). Nevertheless, to gain experience takes time. Therefore, individuals that do not remain at their nesting sites all year round (i.e. migrants) can be more vulnerable to negative effects of ecological traps than are sedentary birds, because they have shorter time to evaluate the actual conditions of their nesting sites after their arrival (Kokko and Sutherland 2001; Kristan 2003; Battin 2004; Winter et al. 2006). To our knowledge, however, this issue has never been evaluated in studies investigating bird ecology.

The aim of this article is to review the literature studying the ecological trap phenomenon in birds. We analyse whether existence of ecological traps is associated with particular habitat types, geographic areas, and/or life strategies of bird species such as migration and nesting place. We also discuss if ecological traps appear in habitats not altered by humans, and the utility of this concept for species protection. 


\section{MATERIAL AND METHODS}

Articles investigating the ecological trap phenomenon in birds were mainly searched according to the key words "ecological trap" and "birds" using the databases of Web of Science, Wiley, EBSCO and Springer Link, as well as according to the references of papers identified in this way. Those studies examining ecological trap using artificial nests were not included into our analysis, because this methodological approach does not sufficiently enable testing of nesting birds' habitat preferences (Söderström et al. 1998, Yahner and Piergallini 1998).

To analyse whether the existence of an ecological trap is linked to specific geographical regions and/or habitat types, we distinguish between six geographical regions (Europe inclusive of Fuerteventura, North America, South America, Asia, Africa, Australia \& New Zealand) and five habitat types (forest, open habitats, suburban habitats, coastal zones and small islands, and unclassified mosaic of different habitats). Open habitats contained such habitat types as arable fields, meadows or wetlands. In addition, habitat types such as cities with suburban zones and farmland were considered as man-affected habitats, whereas those like forests, meadows, wetlands or deserts were classified as natural habitats. From the viewpoint of life strategies, we distinguished between migratory and sedentary species. Moreover, birds were divided into four groups according to their nesting sites (ground, shrub, tree, cavity in the ground or tree; del Hoyo et al. 1992-2011).

\section{RESULTS}

We identified 47 articles examining the ecological trap hypothesis in birds. However, nine studies (19.2\%) only discussed possible effects of ecological traps on bird nesting success and did not test it. Therefore, only 38 papers were included into the ensuing analyses. We found that existence of an ecological trap has, and has not been supported in $14(29.8 \%)$ and $24(51.1 \%)$ studies, respectively (Table 1). In addition, most studies examining the ecological trap hypothesis had tested the effect of habitat fragmentation and management $(39.5 \%, \mathrm{n}=15)$ or the effect of direct human influence $(29.0 \%, \mathrm{n}=11)$. The existence of an ecological trap has mainly been supported in studies examining the presence of exotic species $(80.0 \%, \mathrm{n}=4$; Table 1$)$.

Most studies examining the ecological trap phenomenon have been conducted in North America $(60.5 \%, n=23)$, followed by Europe $(34.2 \%, n=13)$. Whereas $57.1 \%(n=8)$ of European studies supported the hypothesis, among the North American studies this figure was only $42.9 \%(n=6$; Table 1$)$. Only a few studies have been implemented in other regions (South America, $n=1$; Australia \& New Zealand, $n=1$ ) and none of these have supported the ecological trap phenomenon. Moreover, to our knowledge, no such study has been conducted either in Africa or the Asian region.

Regarding habitat type, the ecological trap hypotheses has been most studied in open habitats (i.e. arable fields, meadows and wetlands; $n=16)$ and forest habitats $(n=15)$. Only 3 studies came from urban habitats and 2 investigations concerned coastal zones and small islands $(5.3 \%$, Table 1). We revealed that ecological traps appeared more frequently in open habitats $(60.0 \%)$ than in forest habitats $(50.0 \%)$. There was no difference in detection of ecological traps between anthropogenic and natural biotopes, however, because the hypothesis was supported in 4 (36.4\%) of 11 studies in anthropogenic habitat types and in 9 $(39.13 \%)$ of 23 studies in natural habitat types. 
We found that the ecological trap phenomenon has been tested more frequently in migratory species $(n=24)$ than in sedentary species $(n=9)$. In addition, it has been supported in the same proportion in relation to migratory $(41.7 \%)$ and sedentary species (44.4\%). In two studies it was not possible to distinguish its effect on sedentary versus migratory species, because these had investigated migratory and sedentary species simultaneously. From the viewpoint of nest position, we found that ground nesting species suffered less from ecological traps (2 cases out of 12, or 17\%) than did birds using another nesting strategy (Table 1).

\section{DISCUSSION}

To our knowledge, the overall number of studies on the topic of ecological traps is not large (see also Pärt et al. 2007), even though their significance for species protection is unquestionable. This is probably because ecological traps are very problematic to test (Robertson and Hutto 2006). Not only must nesting preferences and the fitness of populations (i.e. nest density, fitness and reproductive success of individuals) be investigated, but also the habitat quality (i.e. food resources, rate of nest predation and parasitization). Hence, there is also insufficiency of sample size in many studies (e.g. Remeš 2003, Machicote et al. 2004).

Although the papers we reviewed are also significantly biased toward North American studies, we found that the hypothesis of ecological traps was more frequently supported in Europe than in North America. This difference can be due to the higher human population density on the European continent (http://www.worldatlas.com) and, hence, possibly to more frequent habitat changes. However, this aspect merits further investigation.

We also show that ecological traps frequently occurred in relation to exotic species, because exotic predator and plant species may negatively affect the reproduction outputs of birds. For example, the preferred nesting habitat of Cory's Shearwater (Calonectris diomedea) is usually in cliff burrows at the Mediterranean Sea. In the Chafarinas Islands, however, rats (Rattus rattus) have been introduced by humans and their growing population has begun to depredate Cory's Shearwaters, and particularly their nestlings. The birds, however, did not interpret the presence of rats as an environmental cue by which to recognise an unsuitable environment, and they nested there in higher densities than at localities without rats (Igual et al. 2007).

Exotic plant species can also influence the reproductive success of birds (Misenhelter and Rotenbery 2000; Borgmann and Rodewald 2004; Nordby et al. 2008), because their presence causes changes in the structure of the vegetation which can negatively affect the abundance and diversity of food resources (Tallamy 2004), degree of cover, or nest availability (Schmidt and Whelan 1999). For instance, the Old World migratory species Blackcap (Sylvia atricapilla) had higher reproductive success in primary gallery forests in Moravia, even though its nesting density is twice as high in secondary forests of Black Locust (Robinia pseudacacia; Remeš 2003). Birds preferred Black Locust growths probably because this tree produces its foliage earlier in spring than do native woody species, and therefore it offers early cover and potential nesting places (so-called attractive sink biotopes; see Delibes et al. 2001 a, b; Aldridge and Boyce 2007).

The selection of a nesting place itself occurs on the basis of direct (amount of food resources, shelters, nesting opportunities, etc.) and/or indirect cues (e.g. the number of individuals of the same species or absence of a predator; Andrén 1990; Kokko and Sutherland 2001; Schlaepfer et al. 2002; Schlaepfer 2003; Roos and Pärt 2004; Eggers et al. 
2005). The more complete information an individual has about a given biotope, the better is its judgement (Battin 2004; Kokko and Sutherland 2001). Simply speaking, good judgement of habitat quality requires sufficiency of time (Sol and Lefebvre 2000; Donovan and Thompson 2001; Robertson and Hutto 2007). Nevertheless, some migratory species can compensate their shortened time for habitat evaluation by copying the nesting strategies of sedentary species (heterospecific habitat copying hypothesis; see Parejo et al. 2006). Therefore, the risk of nesting failure associated with ecological traps did not differ between migratory and sedentary species in our data set.

We also found that the lowest occurrence of ecological traps was among ground nesting species. This can probably be affected by the fact that 8 of 12 papers studying ground nesters were from North America, where the appearance of the ecological trap phenomenon was also low.

Our findings show that ecological traps are more associated with open habitats. Most of the open habitats, such as fields, wastelands and meadows, are under greater pressure from human influence, in which cases ecological traps can appear more frequently. Nevertheless, since rapid habitat changes and exotic species usually occur in human settlements, we expected that the ecological trap hypothesis would be more supported in urban habitats. Although there exists a significant number of studies investigating nest success in urban zones (Vierling 2000; Blair 2004; Charter et al. 2007), surprisingly, only one study dealt with the ecological trap phenomenon in an urban environment (Ellison and Brush 2004). Also lacking are studies comparing the rate of nest predation between urban and undisturbed environments, which could thereby elucidate the mechanisms of ecological traps associated with human presence.

Nevertheless, it does seem that natural habitats also may play a significant role in creating ecological traps (Dwernychuk and Boag 1972; Kristan 2003), although works studying these in other than human-influenced environments are almost non-existent. It can be presumed that they can occur in environments stricken by larger natural changes of abiotic (windstorms, flooding, wildfires, volcanic activity) or biotic origin (e.g. Battin [2004] describes changes following invasion of a particular animal species). It is possible that birds which live in rapidly changing environments are adapted to ongoing changes, and that the ecological trap cannot damage them. If a rapid change occurs in a pristine habitat, on the other hand, this can cause more severe consequences, due to low adaptability of the birds to such situations.

It is also possible that ecological traps exist in the landscape on a scale of much finer changes (e.g. a gradual change in the structure of a biotope due to changes in geology, or change in water regime caused by a beaver dam) than are those brought about by natural disasters (Ganter and Cooke 1998). In such cases, however, it would be very difficult to detect these and their evidence is very poor. The one example of an ecological trap within a natural environment that we found, is seen in a study of Argentinian Burrowing Owls (Athene cunicularia), which prefer to nest in burrows with short vegetation cover (Machicote et al. 2004). In this study, the fates of 26 nests were determined. When nesting in burrows of the Plains Viscacha (Lagostomus maximus), the birds had a nesting success rate of $35 \%$, but not a single nest survived in burrows of Big Hairy Armadillos (Chaetophractus villosus). Viscachas, unlike armadillos, regularly graze the surroundings of their burrows, so the soil there is usually without vegetation. However, a study from other localities showed that Burrowing Owls in burrows of armadillos can achieve higher nesting success rates if the soil around their burrows is bare (Harris 1998). Although the authors of that study had not tested habitat preferences and their sample size was low ( $\mathrm{n}=$ 
23), they suggested that burrows of armadillos could, in the case of Burrowing Owls, constitute a local ecological trap (Machicote et al. 2004).

In conclusion, our results indicate that the phenomenon of ecological traps occurs more frequently in Europe and can be driven by direct human influence and presence of exotic species. However, their appearance in pristine habitats should not be ignored. Migratory bird species are not under greater threat due to ecological traps than are sedentary species, which can be affected by their ability to copy the nesting strategies of sedentary species. Although our results have some limitation, mainly because of low sample size, our findings may have practical application in restoration plans for particular bird species groups and geographical regions.

\section{ACKNOWLEDGEMENTS}

We thank Filip Harabiš, Jaroslav Koleček, Juan Rodríguez Ruiz, Michal Vinkler, Pavel Švec, Světlana Vránová and all reviewers for their numerous valuable suggestions at different stages of writing the text. Gale A. Kirking conducted a thorough linguistic revision of the manuscript. This work was supported by grants No. 20094205 from the CIGA ČZU and 2011421103126 from the IGA ČZU.

\section{REFERENCES}

Albrecht, T. (2004). Edge effect in wetland - arable land boundary determines nesting success of Scarlet Rosefinch (Carpodacus erythrinus) in the Czech republic. The Auk. 121 (2), pp. 361-371.

Aldridge, C. L., Boyce, M. S. (2007). Linking occurrence and fitness to persistence: Habitat-based approach for endangered Greater Sage-grouse. Ecological Applications. 17 (2), pp. 508-526.

Andrén, H. (1990). Despotic distribution, unequal reproductive success, and population regulation in the Jay Garrulus glandarius L. Ecology. 71 (5), pp. 1796-1803.

Andrén, H. (1992). Corvid density and nest predation in relation to forest fragmentation: a landscape perspective. Ecology. 73 (3), pp. 794-804.

Andrén, H., Angelstam, P. (1988). Elevated predation rates as an edge effect in habitat islands: Experimental evidence. Ecology. 60 (2), pp. 544-547.

Arlt, D., Pärt, T. (2007). Nonideal breeding habitat selection: a mismatch between preference and fitness. Ecology. 88, pp. 792-801.

Ball, J. R., Bayne, E. M., Machtans, C. S. (2008). Energy sector edge effects on songbird nest fate and nest productivity in the boreal forest of Western Canada: a preliminary analysis. Proceedings of the Fourth International Partners in Flight Conference: Tundra to Tropics, pp. 161-170.

Batáry, P., Winkler, H., Báldi, A. (2004). Experiments with artificial nests on predation in reed habitats. Journal of Ornithology. 145, pp. 59-63.

Battin, J. (2004). When good animals love bad habitats: Ecological traps and the conservation of animal populations. Conservation Biology. 18 (6), pp. 1482-1491.

Bayne, E. M., Hobson, K. A. (2001). Effects of habitat fragmentation on pairing success of Ovenbirds: importance of male age and floater behavior. The Auk. 118 (2), pp. 380-388.

Berg, Å. (2008). Habitat selection and reproductive success of Ortolan Buntings Emberiza hortulana on farmland in central Sweden - the importance of habitat heterogeneity. Ibis. 150, pp. 565-573. 
Best, L. B. (1986). Conservation tillage: ecological traps for nesting birds? Wildlife Society Bulletin. 14, pp. 308-317.

Blair, R. (2004). The effects of urban sprawl on birds at multiple levels of biological organization. Ecology and Society. 9 (5), Retreieved January 28, 2011 from http://www.ecologyandsociety. org/vol9/iss5/art2/ inline.html.

Borgmann, K. L., Rodewald, A. D. (2004). Nest predation in an urbanizing landscape: the role of exotic shrubs. Ecological Applications. 14 (6), pp. 1757-1765.

Bosschieter, L., Goedhart, P. W. (2005). Gap crossing decisions by Reed Warblers (Acrocephalus scirpaceus) in agricultural landscapes. Landscape Ecology. 20, 455-468.

Brotons, L., Herrando, S. (2003). Effect of increased food abundance near forest edges on flocking patterns of Coal Tit Parus ater winter groups in mountain coniferous forests. Bird Study. 50, pp. 106111

Campomizzi, A. J., Morrison, M. L., Farrell, S. L., Wilkins, R. N., Drees, B. M., Packard, J. M. (2009). Red Imported Fire Ants can decrease songbird nest survival. The Condor. 111 (3), pp. 534537.

Carrete, M., Serrano, D., Illera, J. C., López, G., Vögeli, M., Delgado, A., Tella, J. L. (2009). Goats, birds, and emergent diseases: apparent and hidden effects of exotic species in an island environment. Ecological Applications. 19 (4), pp. 840-853.

Chace, J. F., Walsh, J. J. (2006). Urban effects on native avifauna: A review. Landscape and Urban Planning. 74, pp. 46-69.

Chapa - Vargas, L., Robinson, S. K. (2006). Nesting success of a songbird in a complex floodplain forest landscape in Illinois, USA: local fragmentation vs. vegetation structure. Landscape Ecology. 21 (4), pp. 525-537.

Charter, M., Izhaki, I., Bouskila, A. \& Leshem, Y. (2007). Breeding Succes of the Eurasian Kestrel (Falco tinnunculus) nesting on buildings in Israel. Journal of Raptor Research. 41 (2), pp. 139-143.

del Hoyo, J., Elliott, A., Sargatal, J., Christie, D. A. (1992 - 2011). Handbook of the Birds of the World. 1 - 16. Lynx Edicions.

Delibes, M., Gaona, P., Ferreras, P. (2001). (a). Effects of an attractive sink leading into maladaptive habitat selection. The American Naturalist. 158 (3), pp. 277-285.

Delibes, M., Ferreras, P., Gaona, P. (2001). (b). Attractive sinks, or how individual behavioural decisions determine source-sink dynamics. Ecology Letters. 4, pp. 401-403.

Deng, W.-H., Zheng, G.-M., Gao, W. (2003). Nesting success of the meadow bunting along habitat edges in northeastern China. Journal of Field Ornithology. 74 (1), pp. 37-44.

Donovan, T. M., Thompson, F. R. (2001). Modelling the ecological trap hypothesis: a habitat and demographic analysis for migrant songbirds. Ecological Applications. 11, pp. 871-882.

Dwernychuk, L.W., Boag, D.A. (1972). Ducks nesting in association with gulls - an ecological trap? Canadian Journal of Zoology. 50, pp. 559-563.

Eggers, S., Griesser, M., Anderssen, T., Ekman, J. (2005). Nest predation and habitat change interact to influence numbers. Oikos. 111, pp. 150-158.

Ellison, K., Brush, T. (2004). Hooded Oriole nest silure associated with a novel nest site. Western Birds. 35, pp. 71-78.

Fahrig, L. (2003). Effects of habitat fragmentation on biodiversity. Annual Review of Ecology, Evolution, and Systematics. 34, pp. 487-515.

Fernández - Juricic, E., Jokimäki, J. (2001). A habitat island approach to conserving birds in urban landscapes: case studies from southern and northern Europe. Biodiversity and Conservation. 10, pp. 2023-2043. 
Fernández - Juricic, E., Sanz, R., Sallent, A. (2001). Frequency - dependent predation by birds at edges and interiors of woodland. Biological Journal of the Linnean Society. 73 (1), pp. 43-49.

Flaspohler, D. J., Temple, S. A., Rosenfield, R. N. (2001). Species-specific edge effects on nest success and breeding density in a forested landscape. Ecological Applications. 1, pp. 32-46.

Ganter, B., Cooke, F. (1998). Colonial nesters in a deteriorating habitat: site fidelity and colony dynamics of Lesser Snow Geese. The Auk. 115 (3), pp. 642-652.

Gates, E. J., Gysel, L. W. (1978). Avian nest dispersion and fledging success in field - forest ecotones. Ecology. 59 (5), pp. 871-883.

Gilroy, J. J., Sutherland, W. J. (2007). Beyond ecological traps: Perceptual errors and undervalued resources. Trends in Ecology and Evolution. 22 (7), pp. 351-356.

Hansson, L. (1994). Vertebrate distributions relative to clear - cut edges in a boreal forest landscape. Landscape Ecology. 9 (2), pp. 105-115.

Harris, G. (1998). A guide to the birds and mamals of coastal Patagonia. Princeton University Press.

Hazler, K. R., Amacher, A. J., Lancia, R. A., Gerwin, J. A. (2006). Factors influencing Acadian Flycatcher nesting success in an intensively managed forest landscape. Journal of Wildlife Management. 70 (2), pp. 532-538.

Igual, J. M., Forero, M. G., Gomez, T., Oro, D. (2007). Can an introduced predator trigger an evolutional trap in a colonial seabird? Biological Conservation. 137, pp. 189-196.

Jones, Z. F., Bock, C. E. (2005). The Botteri's Sparrow and exotic Arizona grasslands: an ecological trap or habitat regained. Condor. 107 (4), pp. 731-741.

Keeler, M. S., Chew, F. S. (2008). Escaping an evolutionary trap: preference and performance of a native inscet on an exotic invasive host. Oecologia. 156, pp. 559-568.

Kershner, E. L., Bollinger, E. K. (1996). Reproductive success of grassland birds at east-central Illinois airports. American Midland Naturalist 136. (2), pp. 358-366.

Klein, Á., Nagy, T., Csörgő, T., Mátics, R. (2007). Exterior nest-boxes may negatively affect Barn Owls Tyto alba survival: An ecological trap. Bird Conservation International. 17, pp. 273-281.

Kokko, H., Sutherland, W. J. (2001). Ecological traps in changing environments: Ecological and evolutionary consequences of a behaviourally mediated Allee effect. Evolutionary Ecology Research. 3, pp. 537-551.

Kragten, S., de Snoo, G. (2007). Nest success of Lapwings Vanellus vanellus on organic and conventional arable farms in the Netherlands. Ibis. 149, pp. 742-749.

Kriska, G., Malik, P., Szivák, I., Horváth, G. (2008). Glass buildings on river banks as "polarized light traps" for mass-swarming polarotactic Caddis Flies. Naturwissenschaften. 95, pp. 461-467.

Kristan, W. B. III. (2003). The role of habitat selection behavior in population dynamics: source sink systems and ecological traps. Oikos. 103, pp. 457-468.

Leston, L. V. A., Rodewald, A. D. (2006). Are urban forests ecological traps for understory birds? An examination using Northern Cardinals. Biological Conservation. 131, pp. 566-574.

Lindell, C. A. (2008). The value of animal behavior in evaluations of restoration success. Restoration Ecology. 16 (2), pp. 197-203.

Machicote, M., Branch, L. C., Villarreal, D. (2004). Burrowing Owls and burrowing mammals: are ecosystem engineers interchangeable as facilitators? Oikos. 106, pp.527-535.

Mack, R. N., Simberloff, D., Lonsdale, W. M., Evans, H., Clout, M., Bazzaz, F. A. (2000). Biotic invasions: cause, epidemiology, global consequences, and control. Ecological Applications. 10 (3), pp. 689-710. 
Mänd, R., Tilgar, V., Lõhmus, A., Leivits, A. (2005). Providing nest boxes for hole-nesting birds Does habitat matter? Biodiversity and Conservation. 14, pp. 1823-1840.

Mannan, R. W., Steidl, R. J., Boal, C. W. (2008). Identifying habitat sinks: a case study of Cooper's Hawks in an urban environment. Urban Ecosystem. 11, pp. 141-148.

Manu, S., Peach, W., Cresswell, W. (2007). The effects of edge, fragment size and degree of isolation on avian species richness in highly fragmented forest in West Africa. Ibis. 149, pp. 287-297.

Martínez-Abraín, A., Viedma, C., Bartolomé, M. A., Gómez, J. A., Oro, D. (2007). Hunting sites as ecological traps for coots in southern Europe: Implications for the conservation of a threatened species. Endangered Species Research. 3, pp. 69-76.

Marzluff, J. M., Ewing, K. (2004). Restoration of fragmented landscapes for the conservation of birds: A general framework and specific recommendations for urbanizing landscapes. Restoration Ecology. 9 (3), pp. 280-292.

Marzluff, J. M., Neatherlin, E. (2006). Corvid response to human settlements and campgrounds: causes, consequences and challenges for conservation. Biological Conservation. 130, pp. 301-314.

McGowan, K. J. (2001). Demographic and behavioral comparisons of suburban and rural American Crows. Chapter 17 In J. M. Marzluff, R. Bowman \& R. Donnelly (Eds.): Avian Ecology and Conservation in an Urbanizing World (pp. 365-381). Kluwer Academic Press, Norwell, MA.

Miner, B. G., Sultan, S. E, Morgan, S. G., Padilla, D. K., Relyea, R. A. (2005). Ecological consequences of phenotypic plasticity. Trends in Ecology and Evolution. 20 (12), pp. 685-692.

Misenhelter, M. D., Rotenberry, J. T. (2000). Choices and consequences of habitat occupancy and nest site selection in Sage Sparrows. Ecology. 81 (10), pp. 2892-2901.

Newhouse, M. J., Marra, P. P., Johnson, L. S. (2008). Reproductive success of House Wrens in suburban and rural landscapes. Wilson Journal of Ornithology. 120 (1), pp. 99-104.

Nordby, J. C., Cohen, A. N., Beissinger, S. R. (2008). Effects of a habitat-altering invader on nesting sparrows: an ecological trap? Biological Invasions. 11 (3), pp. 565-575.

Parejo, D., Oro, D., Danchin, E. (2006). Testing habitat copying in breeding habitat selection in a species adapted to variable environments. Ibis. 148, pp. 146-154.

Pärt, T., Arlt, D., Villard, M.-A. (2007). Empirical evidence for ecological traps: a two-step model focusing on individual decisions. Journal of Ornithology. 148 (Suppl 2), pp. 327-S332.

Paton, P. W. C. (1994). The effect of edge on avian nest success - how strong is the evidence. Conservation Biology. 8 (1), pp. 17-26.

Pelicice, F. M., Agostinho, A. A. (2008). Fish-passage facilities as ecological traps in large neotropical rivers. Conservation Biology. 22 (1), pp. 180-188.

Pell, A. S., Tidemann, C. R. (1997). The impact of two exotic hollow-nesting birds on two native parrots in savannah and woodland in Eastern Australia. Biological Conservation. 79, pp. 145-153.

Pérot, A., Villard, M.-A. (2009). Putting density back into the habitat quality equation: case study of an open-nesting forest bird. Conservation Biology. 23 (6), pp. 1550-1557.

Pidgeon, A. M., Radeloff, V. C., Matthews, N. E. (2003). Landscape-scale patterns of Black-throated Sparrow (Amphispiza bilineata) abundance and nest success. Ecological Applications. 13, pp. 530542.

Powell, L. L., Hodgman, T. P., Glanz, W. E., Osenton, J. D., Fisher, C. M. (2010). Nest-site selection and nest survival of the Rusty Blackbird: does timber management adjacent to wetlands create ecological traps? The Condor. 112 (4), pp. 800-809.

Pöysä, H., Pöysä, S. (2002). Nest-site limitation and density dependence of reproductive output in the Common Goldeneye Bucephala clangula: implications for the management of cavity-nesting birds. Journal of Applied Ecology. 39, pp. 502-510. 
Purcell, K. L., Verner, J. (1998). Density and reproductive success of California Towhees. Conservation Biology. 12 (2), pp. 442-450.

Rantanen, E. M., Buner, F., Riordan, P., Sotherton, N., Macdonald, D. W. (2010). Habitat preference and survival in wildlife reintroductions: an ecological trap in reintroduced Grey Partridges. Journal of Applied Ecology. 47, pp. 1357-1364.

Reed, J. M. (1999). The role of behavior in recent avian extinctions and endangerments. Conservation Biology. 13 (2), pp. 232-241.

Remeš, V. (2003). Effects of exotic habitat on nesting success, territory density, and settlement patterns in the Blackcap (Sylvia atricapilla). Conservation Biology. 17 (4), pp. 1127-1133.

Richkus, K. D. (2002). Northern Pintail nest site selection, nest success, renesting ecology and survival in the intensively farmed prairies of Southern Saskatchewan: an evaluation of the ecological trap hypothesis. A dissertation thesis. B. S., Virginia Polytechnic Institute and State University.

Ries, L., Fagan, W. F. (2003). Habitat edges as potentional ecological trap for an insect predator. Ecological Entomology. 28, pp. 567-572.

Ries, L., Sisk, T. D. (2004). A predictive model of edge effects. Ecology. 85 (11), pp. 2917-2926.

Robertson, B. A., Hutto, R. L. (2006). A framework for understanding ecological traps and evaluation of existing evidence. Ecology. 87, pp. 1075-1085.

Robertson, B. A., Hutto, R. L. (2007). Is selectively harvested forest an ecological trap for Olive sided Flycatchers? The Condor. 109, pp. 109-121.

Rodewald, A. D., Shustack, D. P., Hitchcock, L. E. (2010). Exotic shrubs as ephemeral ecological traps for nesting birds. Biological Invasions. 12, pp. 33-39.

Rodriguez, J., Avilés, J. M., Parejo, D. (2011). The value of nestboxes in the conservation of Eurasian Rollers Coracias garrulus in southern Spain. Ibis. 153, pp. 735-745.

Roos, S., Pärt, T. (2004). Nest predators and spatial dynamics of breeding Red-backed Shrikes (Lanius collurio). Journal of Animal Ecology. 73, pp. 117-127.

Schlaepfer, M. A. (2003). Successful lizard eggs in a human-disturbed habitat. Oecologia. 137, pp. 304-311.

Schlaepfer, M. A., Runge, M. C. \& Sherman, P. W. (2002). Ecological and evolutionary traps. Trends in ecology and evolution. 17 (10), pp. 474-480.

Schlaepfer, M. A., Sherman, P. W., Blossey, B., Runge, M. C. (2005). Introduced species as evolutionary traps. Ecology Letters. 8, pp. 241-246.

Schmidt, K. A., Whelan, C. J. (1999). Effects of exotic Lonicera and Rhamnus on songbird nest predation. Conservation Biology. 13 (6), pp. 1502-1506.

Sekercioglu, C. H., Loarie, S. R., Oviedo Brenes, F., Ehrlich, P. R., Daily, G. C. (2007). Persistence of forest birds in the Costa Rican agricultural countryside. Conservation Biology. 21 (2), pp. 482-494.

Shochat, E., Patten, M. A, Morris, D. W., Reinking, D. L., Wolfe, D. H., Sherrod, S. K. (2005). Ecological traps in isodars: effects of tallgrass prairie management on bird nest success. Oikos. 111, pp. 159-169.

Smith, L. A., Nol, E., Burke, D. M., Elliott, K. A. (2007). Nest-site selection of Rose-breasted Grosbeaks in southern Ontario. The Wilson Journal of Ornithology. 119 (2), pp. 151-161.

Soderström, B, Pärt, T., Ryden, J. (1998). Different predator faunas and nest predation risk on ground and shrub nests at forest ecotones: an experiment and a review. Oecologia. 117, pp. 108-118.

Sol, D., Lefebvre, L. (2000). Behavioural flexibility predicts invasion success in birds introduced to New Zealand. Oikos. 90, pp. 599-605. 
Steffens, K. E., Seddon, P. J., Mathieu, R., Jamieson, I. G. (2005). Habitat selection by South Island Saddlebacks and Stewart Island Robins reintroduced to Ulva Island. New Zealand Journal of Ecology. 29 (2), pp. 221-229.

Stuart-Smith, A. K., Hayes, J. P. (2003). Influence of residual tree density on predation of artificial and natural sonbird nests. Forest Ecology and Management. 183 (1-3), pp. 159-176.

Tallamy, D. W., 2004: Do alien plants reduce insect biomass? Conservation Biology. 18 (6), pp. 1689-1692.

Thyen, S., Exo, K.-M. (2003). Wadden Sea saltmarshes: Ecological trap or hideway for breeding Redshanks Tringa totanus? Wader Study Group Bulletin. 100, pp. 43-46.

Vergara, P. M., Simonetti, J. A. (2003). Forest fragmentation and rhinocryptid nest predation in central Chile. Acta Oecologica - International Journal of Ecology. 24 (5-6), pp. 285-288.

Verhulst, S., Ooosterbeek, K., Rutten, A. L., Ens, B. J. (2004). Shellfish fishery severely reduces condition and survival of Oystercatchers despite creation of large marine protected areas. Ecology and Society. 9 (1), Retreieved January 28, 2011 from: http://www.ecologyand society.org/vol9/iss1/art17/

Vierling, K. T. (2000). Source and sink habitats of Red-winged Blackbirds in a rural/suburban landscape. Ecological Applications. 10 (4), pp. 1211-1218.

Weidinger, K. (2000). The breeding performance of Blackcap Sylvia atricapilla in two types of forest habitat. Ardea. 88 (2), pp. 225-233.

Weldon, A. J., Haddad, N. M. (2005). The effects of patch shape on Indigo Buntings: evidence for an ecological trap. Ecology. 86, pp. 1422-1431.

Winter, M., Johnson, D. H., Shaffer, J. A., Donovan, T. M., Svedarsky, W. D. (2006). Patch size and landscape effects on density and nesting success of grassland birds. Journal of Wildlife Management. 70 (1), pp. 158-172.

Woodward, A. A., Fink, A. D., Thompson, F. R. III. (2001). Edge effects and ecological traps: effects on shrubland birds in Missouri. Journal of Wildlife Management. 65 (4), pp. 668-675.

Yahner, R. H., Piergallini, N. H. (1998). Effects of microsite selection on predation of artificial ground nests. Wilson Bulletin. 110 (3), pp. 439-442. 
ร

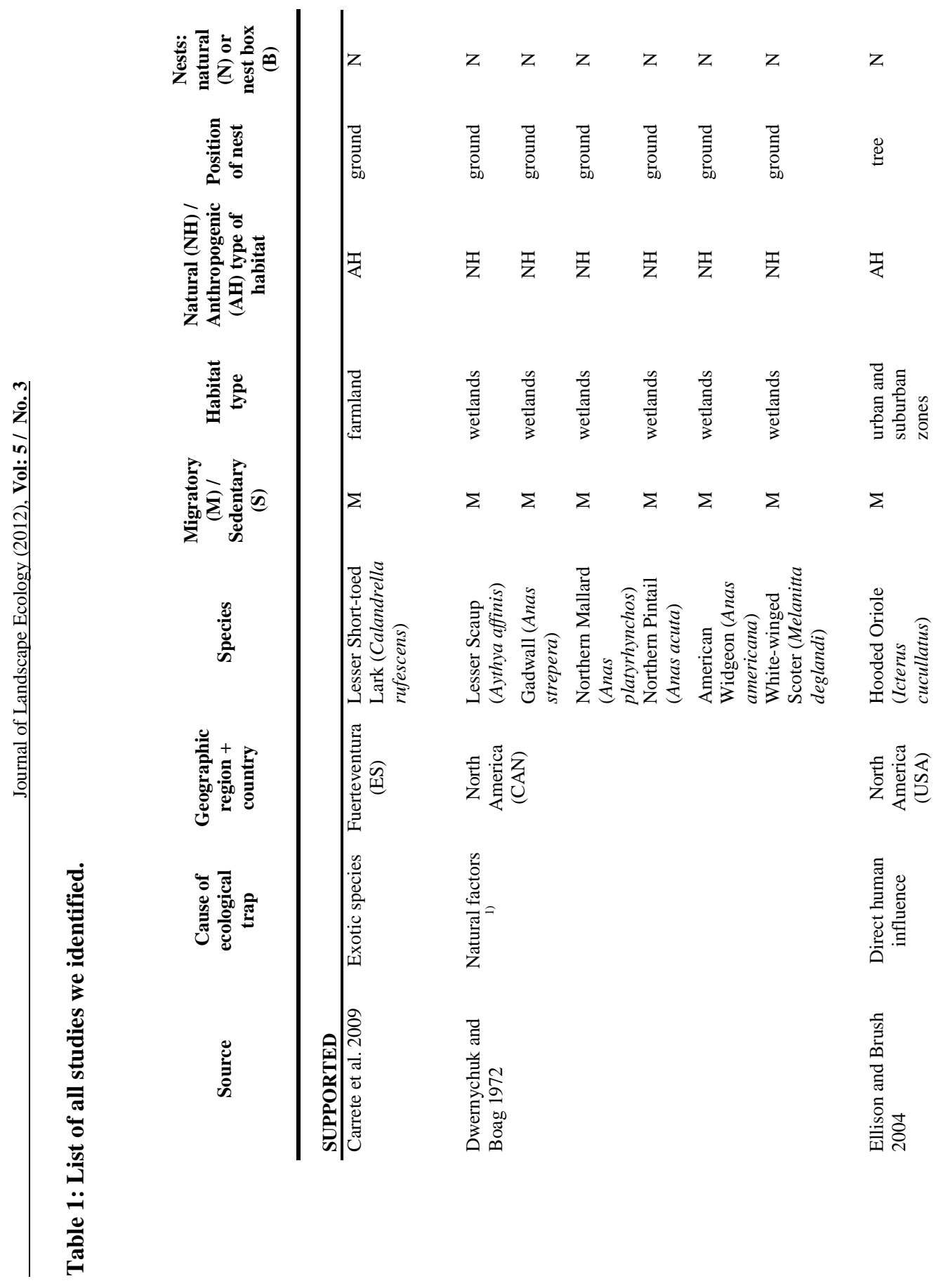




\begin{tabular}{|c|c|c|c|c|c|}
\hline z & 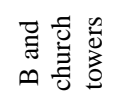 & $\infty$ & $\stackrel{*}{i}$ & z & $\stackrel{*}{i}$ \\
\hline 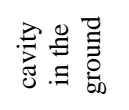 & 言 & 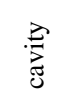 & $\stackrel{*}{i}$ & 亳 & $\stackrel{*}{i}$ \\
\hline T & 胥 & $\frac{\pi}{\bar{z}}$ & $\frac{\pi}{\mathrm{z}}$ & 文 & 孝 \\
\hline
\end{tabular}

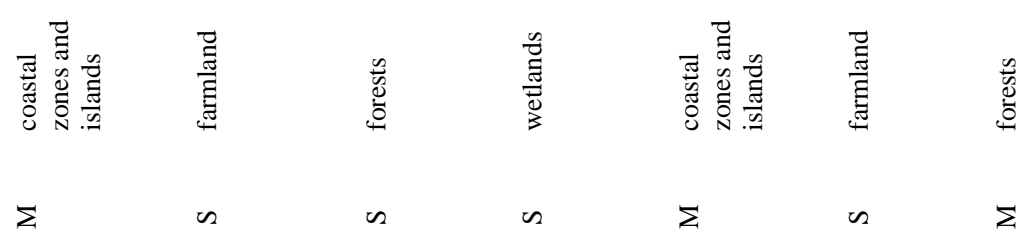

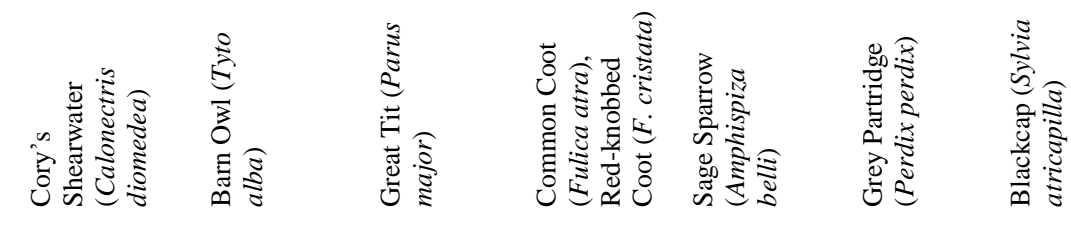

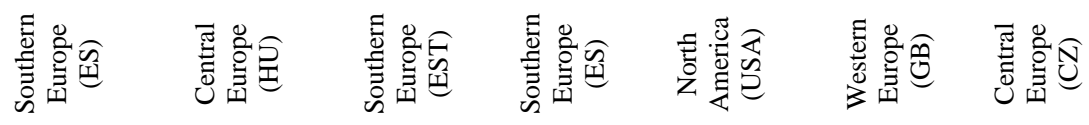

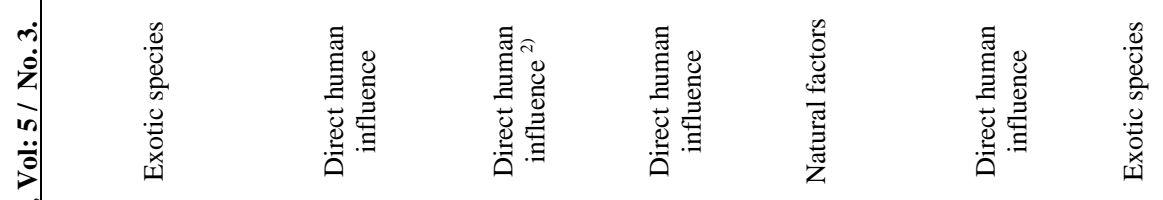

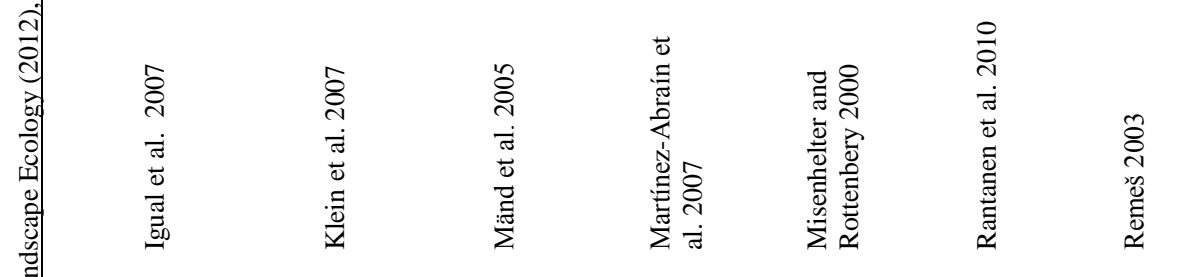




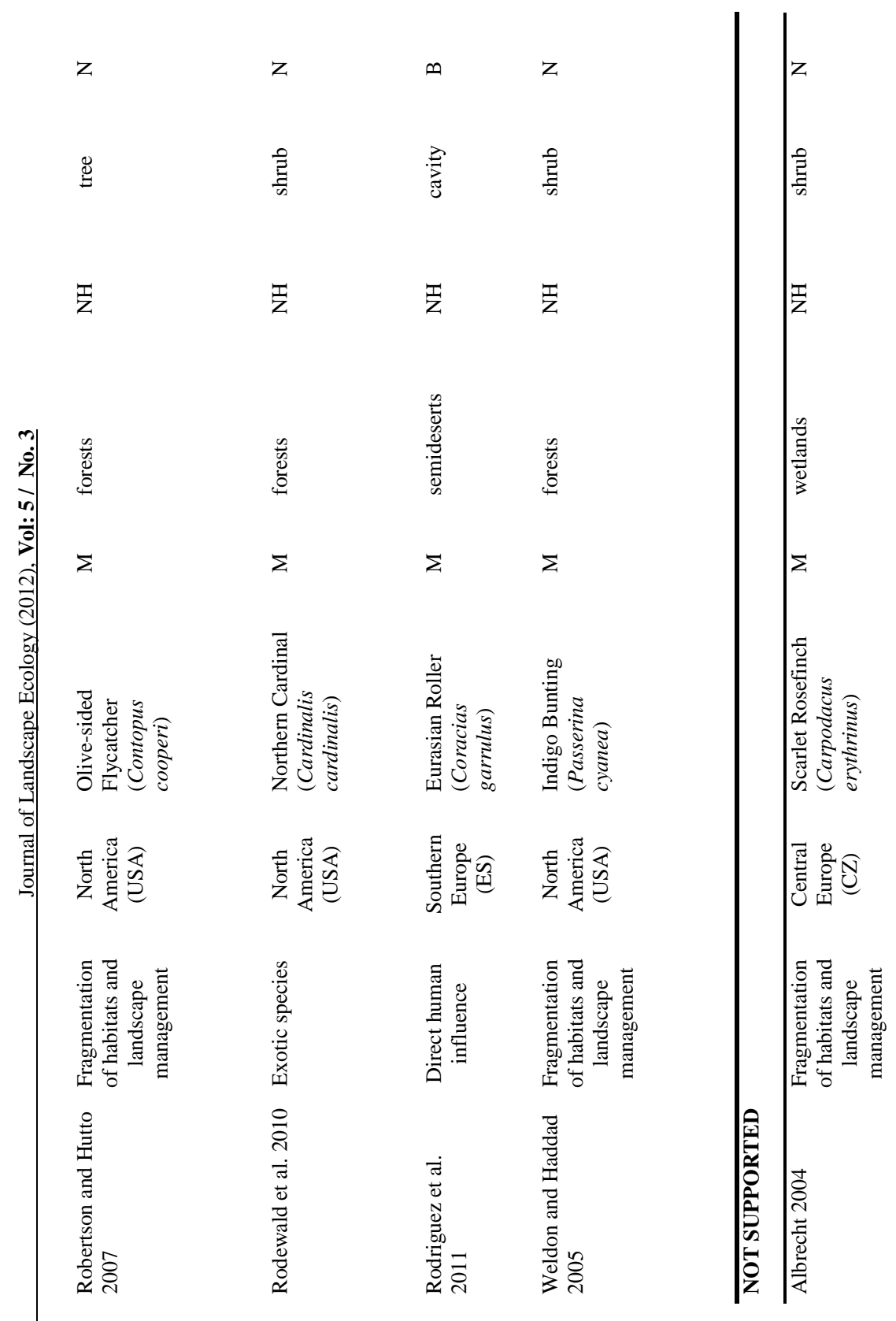




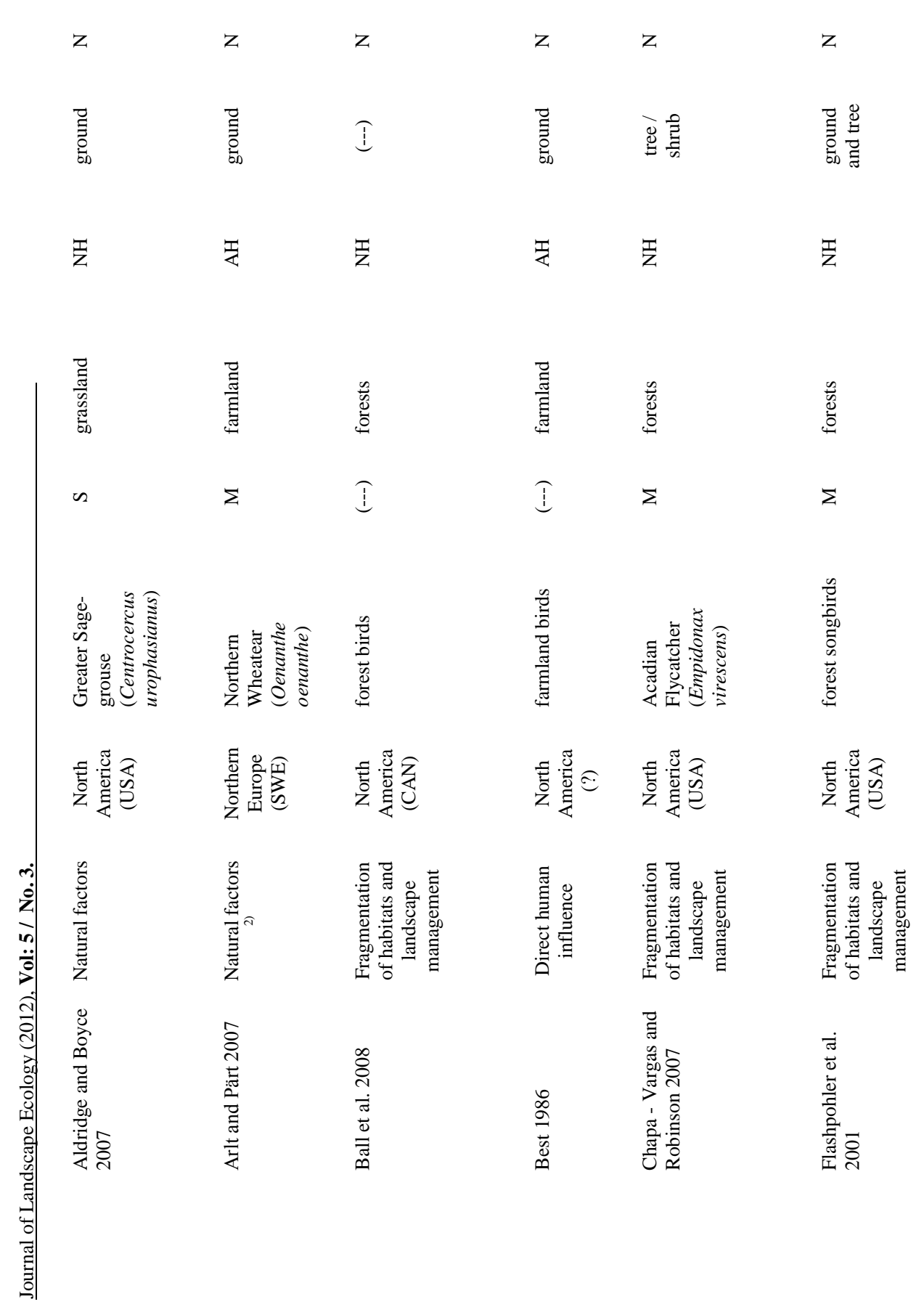

in 
$\bar{n}$

急鼻

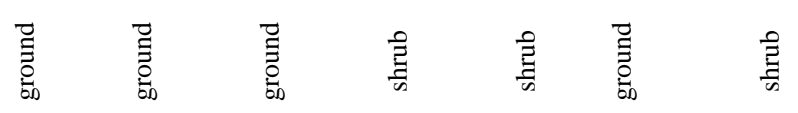

立

元

吾 吾

昙

至言

준

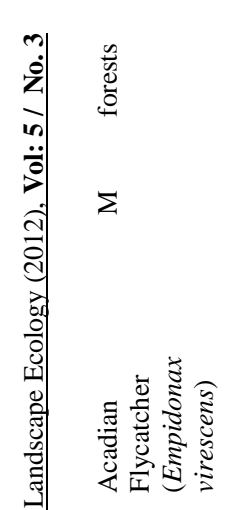

量

歖歖

妾

歖

喜歖

蒁

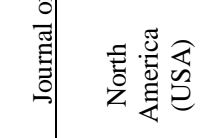

。

his

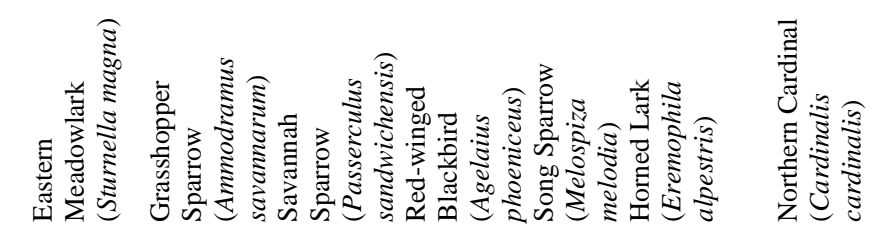

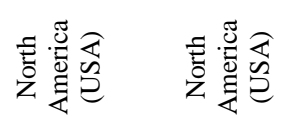

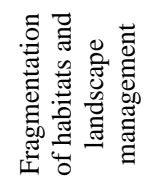

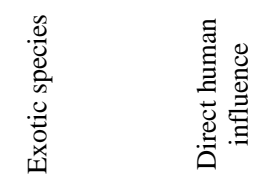

$\frac{1}{4}$
$\frac{\pi}{\pi}$
$\frac{\pi}{0}$
$\frac{\pi}{4}$
$\frac{\pi}{4}$

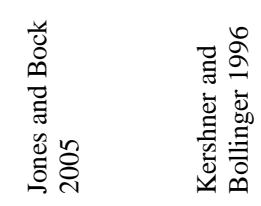

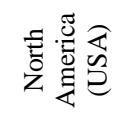
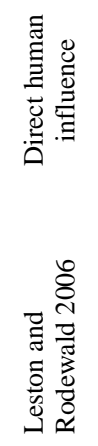


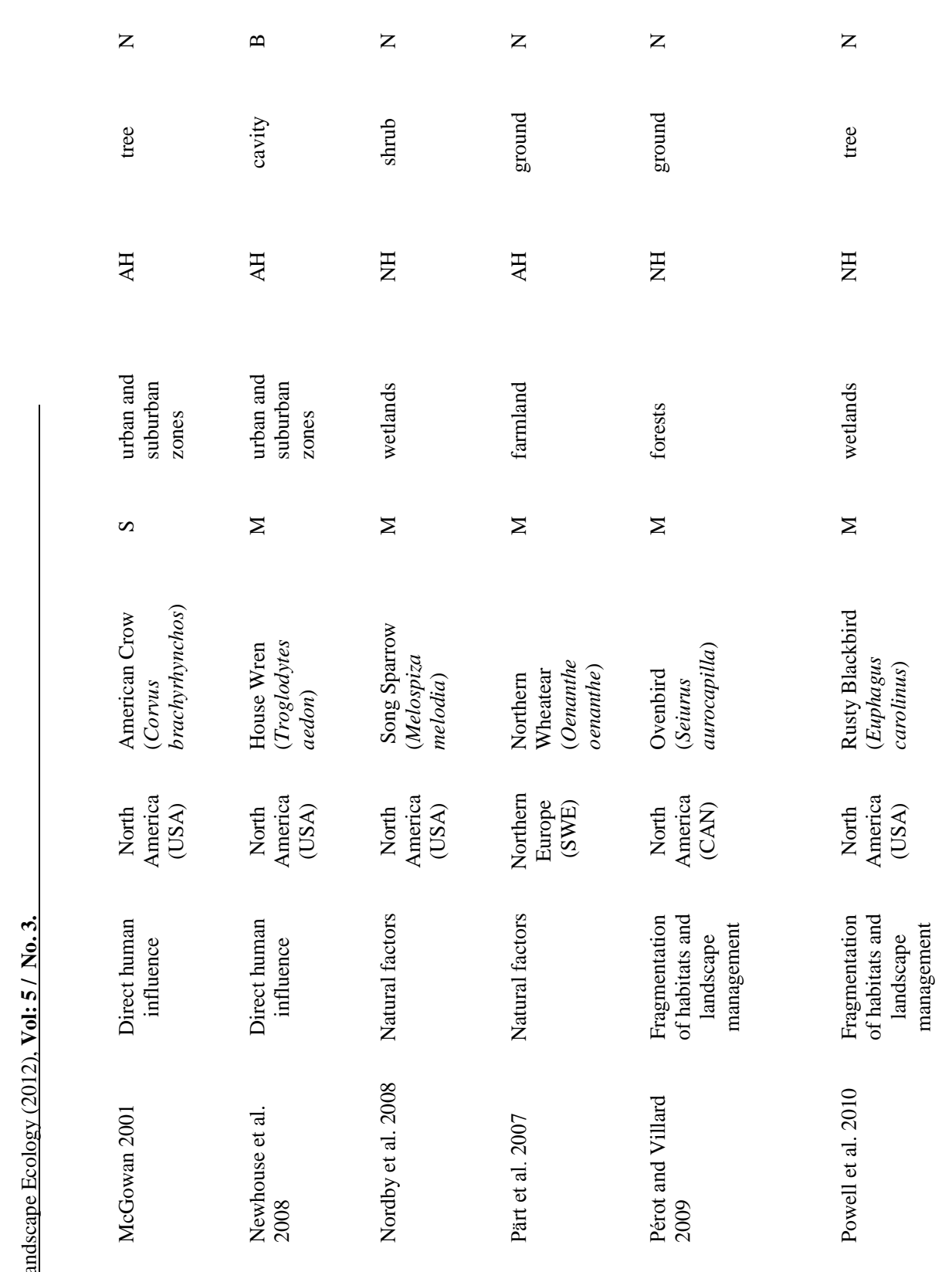


in

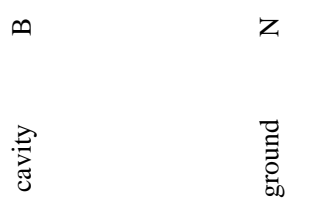

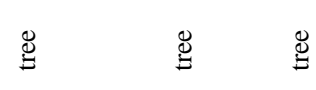

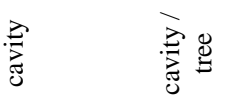

正

装

휴

要要

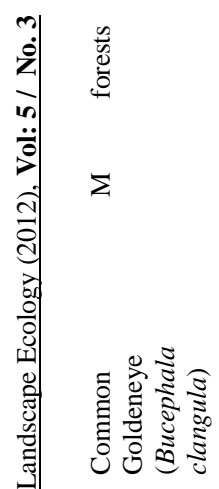

몸

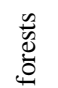

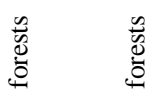

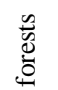

产

흘

$\Sigma$

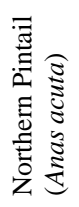

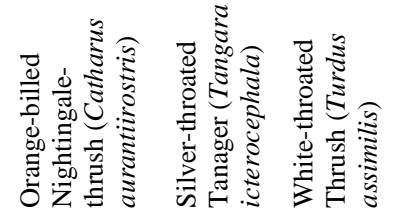

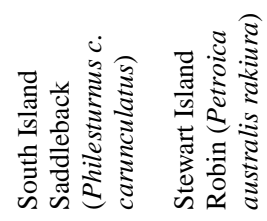

흏ํำ

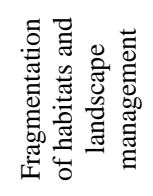

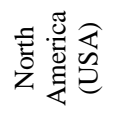

吾蓠蒂

苞

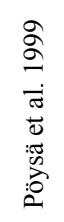

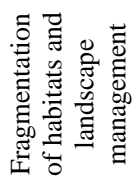

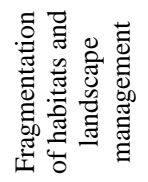

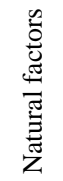

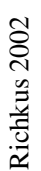

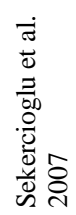

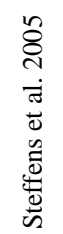




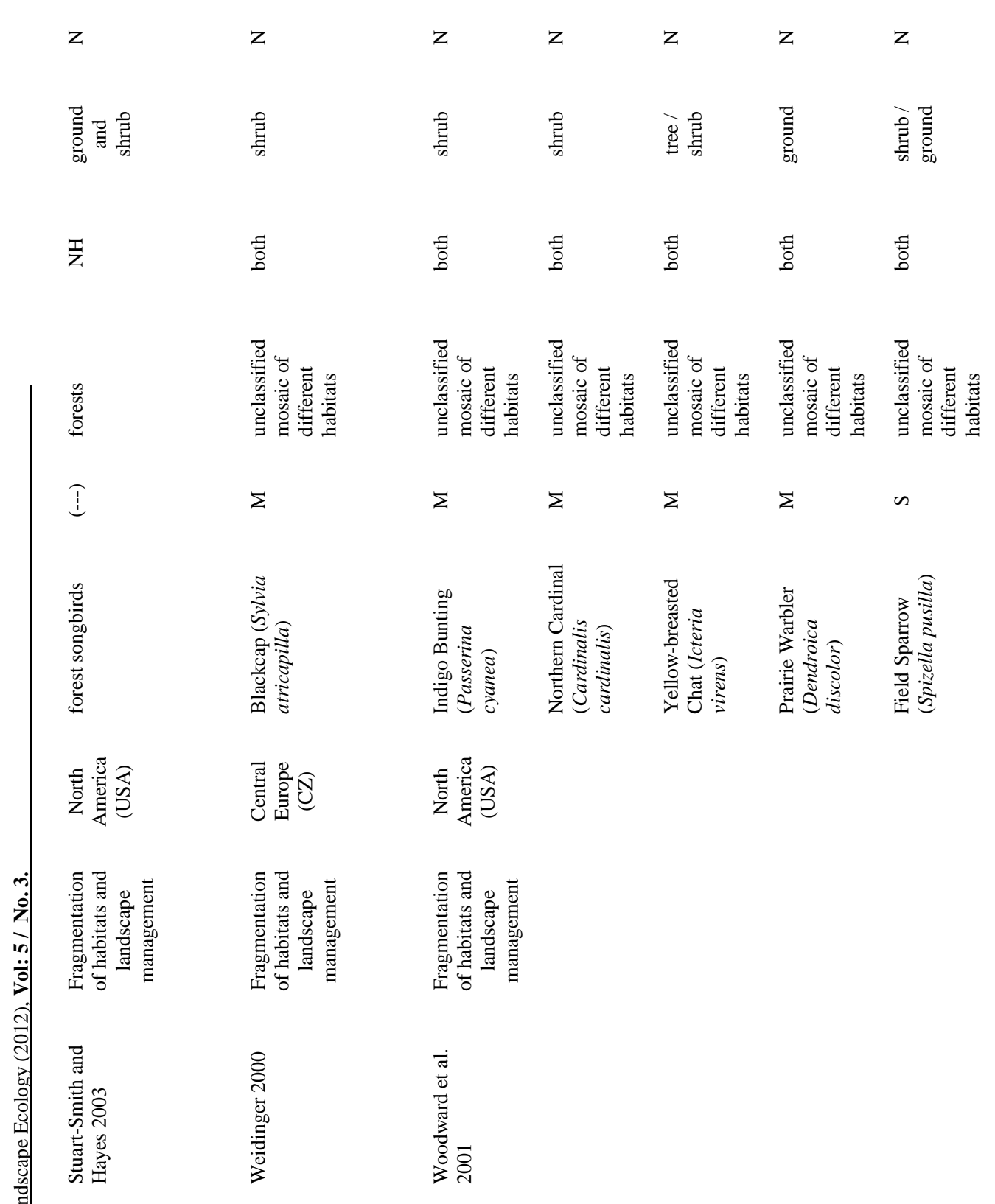


in

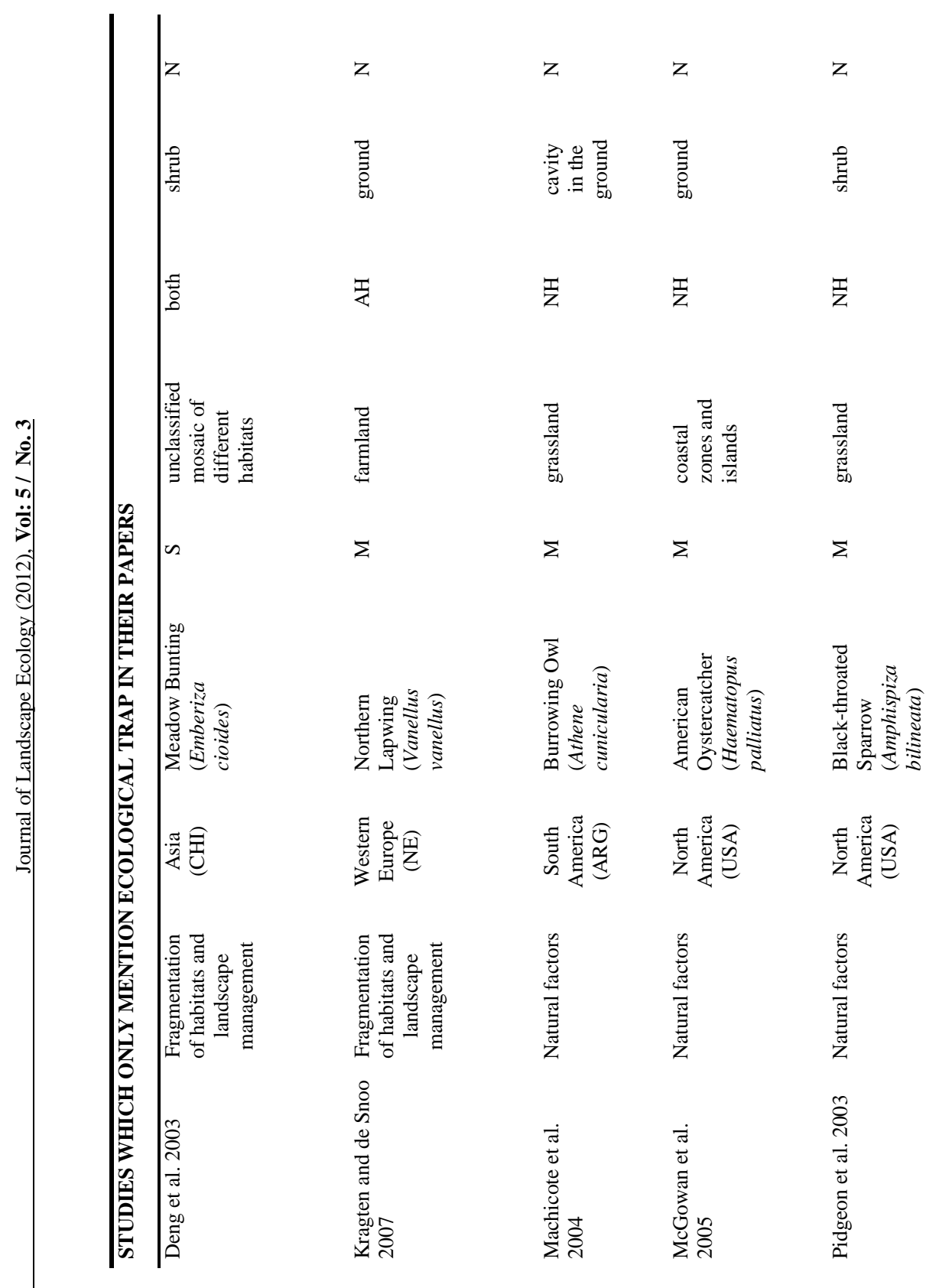




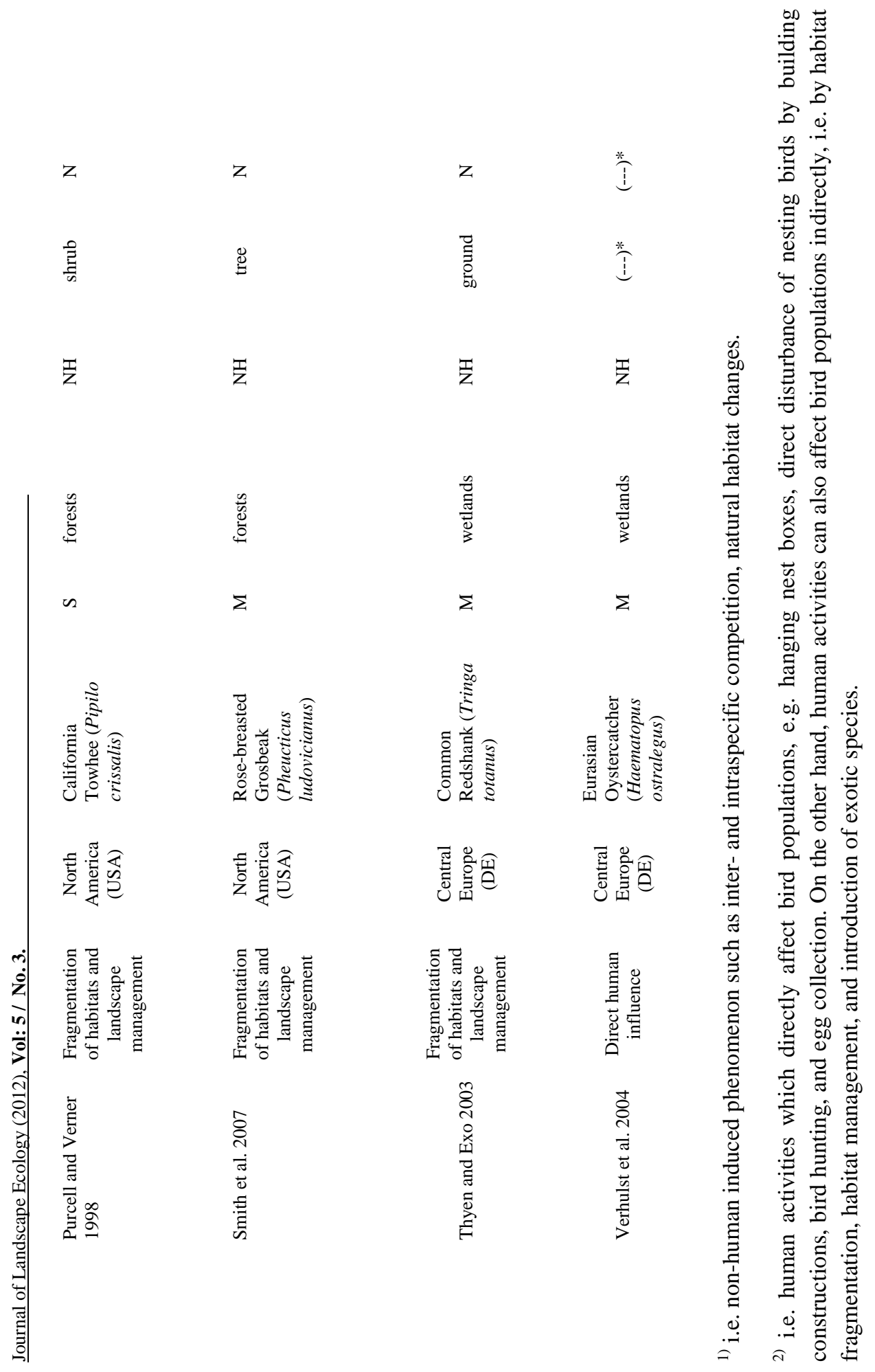

